\title{
Babenko v., ACTIVITIES OF INTERNATIONAL Sidorov V., Savin R. AGROHOLDINGS IN THE WORLD MARKET OF FOREIGN INVESTMENTS: INVESTIGATION OF TRENDS AND FACTORS OF IMPACT IN CURRENT FINANCING CONDITIONS
}

\begin{abstract}
У якості об’єкта дослідження розглядається діяльність міжнародних агрохолдингів. Недостатня формалізачія причинно-наслідкових зв'язків на основі аналітичних залежностей, що визначають перспективи розвитку агрохолдингів, є недоліком дослідження діяльності агрохолдингів в сучасних умовах фінансування. Проведений аналіз тенденцій розвитку підприємств агропромислового комплексу (АПК) України свідчить, що останнім часом спостерігається тенденція до розвитку і територіально-організаційного укрупнення підприємств АПК шляхом формування холдингів, корпорачій, інших агроформувань. Існує також тенденція об'єднання підприємств в агрохолдинги. Це дозволяє компаніям не тільки контролювати якість і собівартість продукцї, що випускається, а й підвищує ймовірність отримання кредитних ресурсів. При цьому зростає роль інвестиційних процесів, розробки методик їх впровадження і ефективного управління ними. Для відображення закономірностей функиіонування агрохолдингів і механізмів їх внутрішніх взаємозв’язків досліджено фактори впливу на їх діяльність в розрізі ї складових. На основі факторного аналізу розроблені системи моделей латентних факторів, що впливають на складові діяльності агрохолдингів. Встановлено, що до них відносяться:

- динаміка інвестування в розширення виробничої діяльності агрохолдингів;

- динаміка витрат і джерел фінансування;

- динаміка впровадження інноваційної діяльності агрохолдингів.

В аспекті динаміки витрат і джерел фінансування найбільш істотними латентними факторами є:

- питома вага агрохолдингів, які впроваджували інновачї;

- загальна сума витрат агрохолдингів на впровадження нових технологій;

- кількість впроваджених нових маловідходних, ресурсозберігаючих процесів.

Завдяки отриманим результатам забезпечується можливість отримання найбільш значущих чинників на основі взаємозв'язку сукупності показників. Це, на відміну від аналогічних відомих відокремлених показників, забезпечує переваги знаходження перспектив розвитку діяльності агрохолдингів на світовому ринку іноземних інвестицій на основі комплексу латентних ключових факторів.
\end{abstract}

Ключові слова: агрохолдинги в умовах фінансування, латентні фактори інвестування в аграрне виробництво.

\section{Introduction}

Every year the global food crisis is growing, the economic and financial crisis is expanding in Ukraine and abroad, the world's natural resources are depleted. There is a general deterioration in the ecological situation, as evidenced by the dynamics of climate change and the deterioration of the health and life of the world population.

These and other reasons indicate the need to intensify the sphere of agricultural production.

Recently, there has been a trend towards the development of enterprises of the agro-industrial complex on the basis of territorial-organizational enlargement - the formation of holdings, corporations, etc. At the same time, current trends in the activities of the agro-industrial sector of Ukraine are based on low-technology production. These trends, as well as the continuing decline in production in the agro-industrial complex, actualizes the need to apply scientific approaches to the study of the mechanism for managing production activities at large agro-enterprises both in Ukraine and abroad.

No less relevant is the study of the activities of international agricultural holdings in the world market of foreign investment. As the world practice shows, the level of investment is one of the main factors influencing the activities of agri-culture in the current financing environment. Therefore, the analysis of the activities of international agricultural holdings and the elucidation of the factors that determine the prospects for the development of agricultural holdings in the global investment market is an actual and practically important task of research.

\section{The object of research and its technological audit}

Since 2005, in the agrarian sector of Ukraine there has been a tendency to the emergence of «big players» (agroholdings), which are present in all sectors of the agrarian 
business: agricultural production, storage, processing, export through own terminals [1]. For example, in the structure of the agrarian sector of the Ukrainian economy more than $30 \%$ of the capacity belongs to large agroholdings, which, first of all, are intended for storing and processing their own crops.

The activity of international agroholdings is considered as an object of research. Data of the Agrarian Exchange of Ukraine, agroportals, Internet resources and other information sources are used to analyze the current state and trends in the development of production activities of agroholdings.

One of the most problematic places is the formalization of factors for the development of agro-associations. Particularly significant practical results can be obtained on the basis of a complex of latent factors taking into account the interrelationship of the set of basic indicators.

\section{The aim and objectives of research}

The aim of research is modeling the development factors of agroholdings in the current socio-economic conditions by establishing cause-effect relationships in the form of analytical dependencies that determine the prospects for the development of agroholdings in the global investment market.

Achieving this aim involves the following tasks:

1. Study of the problems associated with the development of agroholdings in modern investment conditions, namely: the definition of the current state and trends in the development of production activities of agroholdings.

2. Definition of the most significant factors in the development of agricultural holdings.

\section{Research of existing solutions of the problem}

For the consideration of the mechanism for managing the productive activities of agroholdings under certain economic conditions, various models are proposed that show its dynamics, the role and influence of various factors [2-4].

In the 60 s of the XX century the methods of enterprise management prevailed, based on such management models in which scientific research was considered the main development factor and the market as a secondary element.

Such models are called models of technological thrust and the driving force of the market $[5,6]$. In the second model, more attention was paid to the marketing of products. With the development of innovative technologies, a model was developed that balanced the relationship between the role of research and the market, the so-called combined model [7, 8]. Within the framework of this model it was assumed that the management of the enterprise should be accompanied by innovations in the sphere of marketing, management and production [9, 10].

In recent years, interest in the development and management of agro-enterprises, their production and innovation activities in the world has grown very much, which draws the attention of managers and scientists. The emergence of new approaches to the introduction of innovations based on the application of advances in information and communication technologies has acted as a catalyst for the integration and consolidation of business, including the sphere of agricultural production [11]. So, for example, scientists [12] have become developers and distributors of the concept of business modeling innovation (BMI) with the help of Internet resources. In [12] it is noted that BMI is an integral part of the economic behavior of the subject of management.

Scientific and technological achievements in the socalled post-industrial technologies were accompanied by the development of organizational methods and management structure. For example, software or biotechnologies that are fundamentally different from those that are observed in a traditional manufacturing organization and are accompanied by the emergence of new ways of doing business $[8,9,12]$. In addition, it needs to be determined that, despite the fact that the «right» product design is a prerequisite for penetrating new markets, management is crucial, based on the allocation of resources and the establishment of sales channels. This is necessary for the successful execution of business operations [7, 11]. Thus, in the activities of modern foreign enterprises, special importance is given to organizational forms of management.

The analysis of the literature sources based on the chronology of trends in the development of management forms of agroholdings has shown that the mechanisms of development and management of enterprises are accompanied by the emergence of new ways of doing business.

The main are two areas are:

1) use of post-industrial technologies;

2) efforts on the corporate sector to enter new markets and attract new customers.

In modern economic conditions, any agro-industrial enterprise is forced through management to adapt its resource opportunities to external and internal conditions, taking into account the risks associated with instability and complexity of the socio-economic conditions of the domestic and foreign markets. In addition, it is necessary to take into account the specific nature of agricultural production, the main features of which are its sectoral orientation, which leads to the appearance of «agrarian» risks [13]. The main source of risks in agricultural production is the natural and climatic conditions and weather fluctuations leading to loss of production [14]. It must also be taken into account that in a number of cases agricultural raw materials are basically a perishable product, and also one that quickly loses its useful nutritional properties, which must also be taken into account in its production, transportation and storage.

Thus, the specificity of the holding's activities related to the agricultural sphere increases the significance and role of investment processes, as well as the need to study other factors of influence in the current financing environment. Therefore, the definition of the current state and trends in the development of production activities of agroholdings in the world market of foreign investment, modeling of factors of development of agricultural holdings in the current financing environment is an important scientific and practical task.

\section{Methods of research}

During the execution of the work general scientific and special research methods were used:

- analysis and synthesis - to study the features, current status and conditions of the activities of agricultural holdings at the present time; 
- multivariate statistical analysis based on factor analysis to formalize the analytical dependencies of latent factors in the development of agricultural holdings and the formation of the most significant of them.

\section{Research results}

According to the data posted on the sites of the agricultural holding «Harmelia» and the national Agroportal «Latifundist» [15], the first place among vertically integrated com- panies is occupied by the agroholding «UkrLandFarming», the second and third - «Kernel» and «Myronivsky Plant for Manufacturing Groats and Feeds» (Table 1).

The structure of the agricultural holding UkrLandFarming includes 6 sugar plants, 5 seed plants, 111 grain storage facilities. In addition - 19 meat processing plants, 10 farms for growing laying hens, 3 breeding farms, 3 reproducers, 6 feed mills, 3 warehouses for long-term storage of products. It also includes the egg production factory Imperovo Foods and 25 distribution centers.

Table 1

The largest vertically integrated agroholdings of Ukraine

\begin{tabular}{|c|c|c|c|c|}
\hline No. & Name & Kind of activity & Investments, mln. UAH & Leadership \\
\hline 1 & $\begin{array}{l}\text { «UkrLandFarming» } \\
\text { (with«Avangarda») }\end{array}$ & $\begin{array}{l}\text { Crop production (including seed production) } \\
\text { Dairy and meat cattle breeding } \\
\text { Production of eggs and egg products } \\
\text { Sugar production } \\
\text { Meat processing } \\
\text { Storage and trade of grain and industrial crops } \\
\text { Distribution }\end{array}$ & 532 & $\begin{array}{l}\text { The leader in the produc- } \\
\text { tion of grain and eggs } \\
\text { in Ukraine }\end{array}$ \\
\hline 2 & «Kernel» & $\begin{array}{l}\text { Crop production } \\
\text { Export of cereals } \\
\text { Sunflower oil production } \\
\text { Grain storage services }\end{array}$ & 329 & $\begin{array}{l}\text { Leader in the production } \\
\text { and export of sunflower oi }\end{array}$ \\
\hline 3 & $\begin{array}{l}\text { «Myronivsky Plant } \\
\text { for Manufacturing } \\
\text { Groats and Feeds» }\end{array}$ & $\begin{array}{l}\text { Industrial production of chicken meat } \\
\text { Growing of cereals and oilseeds } \\
\text { Manufacture of meat and sausage products }\end{array}$ & 288.5 & $\begin{array}{l}\text { Leader for the production } \\
\text { of poultry meat }\end{array}$ \\
\hline 4 & «Astarta» & $\begin{array}{l}\text { Sugar production } \\
\text { Crop production } \\
\text { Livestock raising }\end{array}$ & 240 & $\begin{array}{l}\text { Leader in the production } \\
\text { of sugar }\end{array}$ \\
\hline 5 & «Harveast» & $\begin{array}{l}\text { Crop production } \\
\text { Livestock raising }\end{array}$ & 220 & Is not a leader \\
\hline 6 & «Agroton» & $\begin{array}{l}\text { Crop production } \\
\text { Livestock raising } \\
\text { Manufacture of food products (сегеals, flour, bakery products, etc.) }\end{array}$ & 209 & Is not a leader \\
\hline 7 & $\begin{array}{l}\text { «Industrial milk } \\
\text { company» }\end{array}$ & $\begin{array}{l}\text { Crop production } \\
\text { Dairy farming } \\
\text { Crop storage and processing } \\
\text { Processing of milk } \\
\text { Potato growing }\end{array}$ & 122.69 & $\begin{array}{l}\text { One of the top ten milk } \\
\text { producers }\end{array}$ \\
\hline 8 & «Privat-agra» & \begin{tabular}{|l} 
Crop production \\
Livestock raising \\
\end{tabular} & 120 & Is not a leader \\
\hline 9 & «Druzhba-Nova» & \begin{tabular}{|l} 
Сrop production \\
Livestock raising
\end{tabular} & 110 & Is not a leader \\
\hline 10 & «Ukгрrominvest» & $\begin{array}{l}\text { Sugar production } \\
\text { Сгор production }\end{array}$ & 96 & Is not a leader \\
\hline 11 & «K5G Agra» & $\begin{array}{l}\text { Crop production } \\
\text { Livestock raising } \\
\text { Seed production } \\
\text { Vegetable growing } \\
\text { Gardening } \\
\text { Processing and production of food products, energy pellets and biofuel }\end{array}$ & 92 & Is not a leader \\
\hline 12 & «VV-Agra» & $\begin{array}{l}\text { Crop production } \\
\text { Livestock raising }\end{array}$ & 85 & Is not a leader \\
\hline 13 & «Glencore» & $\begin{array}{l}\text { Crop production } \\
\text { Trading }\end{array}$ & 80 & Is not a leader \\
\hline 14 & «Nibulon» & $\begin{array}{l}\text { Crop production } \\
\text { Storage and bringing products to market condition } \\
\text { Livestock raising } \\
\text { Fodder production } \\
\text { Processing (production of sausages) } \\
\text { Trading }\end{array}$ & 79 & Is not a leader \\
\hline 15 & «5varogWestGroup» & $\begin{array}{l}\text { Crop production } \\
\text { Livestock raising } \\
\text { Gardening }\end{array}$ & 78.1 & Is not a leader \\
\hline
\end{tabular}

Note: developed by the authors on the basis of data [16] 
According to the national agro portal «Latifundist» and the magazine «Focus», the agroholding «UkrLandFarming» in 2017 became the largest producer of grain and eggs in Ukraine. So, in 2017 the share of the group's market occupied about $33 \%$ of Ukrainian egg production and about $88 \%$ of dry egg products, for grain crops the share of the group was about $4.2 \%$ of the total production in the country [16].

Agroholding Kernel is the leader among producers and exporters of sunflower oil. Seed processing was carried out at seven oil extraction plants in Ukraine and three - in Russia. Thus, the group «Kernel» produces about 7-8\% of the world production of sunflower oil. «Myronivsky Hliboproduct» (MHP) combines the production capacities of the entire technological chain of meat production - from growing and making feeds, hatching eggs, raising cattle and poultry to processing and selling finished products. The meat processing segment in MHP is an integral part of the company's work and produces a wide range of products, including production from smoked chicken and other food products such as foie gras and veal. The main share of the assortment of products falls on the chicken meat of its own production (50\% of the Ukrainian market of industrial production). MHP belongs to one of the most powerful product brands in Ukraine, Nasha Ryaba.

As practice shows, the integration of agricultural production allows farmers not only to control the quality and cost of production, which increases their competitiveness. And also to become more attractive to investors and banks in comparison with other «players» in the agrarian market. However, now in Ukraine the investment climate is unattractive, insufficiently transparent, inconsistent and devoid of appropriate state regulation. Experts in the field of agriculture (Bleyzer International Foundation) recommend a number of measures that can improve the investment attractiveness of Ukraine's agrarian business, namely:

- ensuring transparency and predictability

of agrarian policy;

- protection of investments, providing for guarantees of land lease rights, rights to products, income and profits received as a result of investment;

- establishment of optimal lease periods, sufficient for the effectiveness of investments, which guarantee their stability and duration of business;

- preferential taxation regime; reduction of interference in operational activities;

- development of the infrastructure of agrarian regions; activization of the state in the field of social investment and strategic research in the agricultural sector. But, despite the risk, Ukrainian farmers still manage to attract credit. Thus, the «agrarian» share of Ukraine in the loan portfolio of the European Bank for Reconstruction and Development (EBRD) varies between 20-25\% annually. This in monetary terms is about 200 million euros (Table 2), while the average loan amount in the domestic agribusiness is about 30 million euros. According to the national agricultural portal «Latifundist», the first place for attracting loans from the EBRD is occupied by the agricultural holding «Nibulon», which managed to raise 200 million USD to finance the elevator network [15].

In addition to the EBRD, the appearance of new «players» is expected on the banking market for crediting the agrarian sector. Thus, 12 such banks, such as VABank, Aktabank, Alfa-Bank, Credit Dnepr Bank, Credit Agricole Bank, Nadra Bank, OTP Bank, announced their willingness to lend to the agricultural sector of Ukraine, «FUIB» and «Raiffeisen Bank Aval» [15]. However, the agricultural sector and others are in need of credit. Thus, according to the National Bank of Ukraine, at the end of December 2017 the volume of loans granted to the agro-industrial complex amounted to 37 billion UAH. According to experts, the total industry demand for loans is from 90 to 250 billion $\mathrm{UAH}$ [1]. Of these, the annual requirement for working capital amounts to $7-8$ billion UAH, the rest of the funds are directed to the restoration of fixed assets.

Table 2

The largest investments of the European Bank for Reconstruction and Development in the agrarian sector of the Ukrainian economy in 2017

\begin{tabular}{|c|c|c|}
\hline Company & Amount of funds, mln USD & Purpose of financing \\
\hline «Nibulon» & 200 & $\begin{array}{l}\text { Financing of working capital, creation of } \\
\text { a network of elevators }\end{array}$ \\
\hline «Astarta» & 72 & $\begin{array}{l}\text { Support of dynamic development of the } \\
\text { company in the agro-economic, dairy } \\
\text { and sugar business. Part of the loan } \\
\text { will go to build a biogas plant for the } \\
\text { utilization of beet processing products }\end{array}$ \\
\hline $\begin{array}{l}\text { «Alfred 5. Topfer } \\
\text { International» }\end{array}$ & 50 & $\begin{array}{l}\text { Replenishment of working capital for } \\
\text { agricultural production }\end{array}$ \\
\hline $\begin{array}{l}\text { «Inter-Zapor- } \\
\text { izhzhia» }\end{array}$ & 25 & $\begin{array}{l}\text { Modernization and expansion of exis- } \\
\text { ting production facilities, construction } \\
\text { of a premix plant }\end{array}$ \\
\hline «AgroTrade» & 23 & $\begin{array}{l}\text { Replenishment of working capital, im- } \\
\text { plementation of measures for energy } \\
\text { efficiency and expansion of capacities } \\
\text { for processing and storage of cereals }\end{array}$ \\
\hline «Agrofusion» & 20 & Provision of medium-term working capital \\
\hline «John Deere» & 20 & $\begin{array}{l}\text { Partnership project of the EBRD and Raif- } \\
\text { feisen International in Ukraine. Investing } \\
\text { in innovative technologies based on John } \\
\text { Deеre technology }\end{array}$ \\
\hline $\begin{array}{l}\text { «ED\&F Man } \\
\text { Ukraine» }\end{array}$ & 15.9 & $\begin{array}{l}\text { Investment funds will be used for the } \\
\text { installation of innovative equipment and } \\
\text { for the processing of sugar beets in the } \\
\text { Mykolaiv region }\end{array}$ \\
\hline
\end{tabular}

Note: developed by the authors on the basis of data [15]

In Ukraine, we observe an acute shortage of storage capacity, which in the next three years can significantly increase, so it is not surprising that many agroholdings in their development programs have announced investments in increasing storage capacity [16]:

- «Kernel» plans to build three elevators in the Khmelnytsky region, capacity of 150-200 thousand tons each; - the company «UkrAgroCom» intends to build two elevators in the territory of the Kirovograd region, capacity of 60-70 thousand tons;

- «Creative» company plans to launch two elevator complexes; the company «Ukrainian Agrarian Investments» plans to increase its capacity for storing grain by $75 \%$. 
In addition to the construction of elevators, the companies announced plans to build a seed factory, increase production of sugar, milk, soybean processing capacity, etc. (Table 3 ).

Business development plan for some Ukrainian agricultural holdings

\begin{tabular}{|c|c|c|}
\hline Company & Direction of activity & Development plan \\
\hline \multirow{3}{*}{$\begin{array}{l}\text { «UkrLand- } \\
\text { Far-ming» }\end{array}$} & Poultry farming & $\begin{array}{l}\text { Construction of a plant for the production of egg } \\
\text { powder in the Khmelnitsky region }\end{array}$ \\
\hline & $\begin{array}{l}\text { Meat and dairy cattle } \\
\text { breeding }\end{array}$ & $\begin{array}{l}\text { Construction of five complexes for fattening cattle } \\
\text { in the Rivne region and two dairy complexes in } \\
\text { the Poltava region }\end{array}$ \\
\hline & Production of biofuel & $\begin{array}{l}\text { Construction of } 30 \text { biogas plants in } 18 \text { regions } \\
\text { of Ukraine with a total capacity of more than } \\
750 \text { million } \mathrm{m}^{3} \text { of bio methane per year }\end{array}$ \\
\hline «Kernel» & Pig breeding & $\begin{array}{l}\text { Construction of a pork production complex in } \\
\text { the Poltava region }\end{array}$ \\
\hline «Agratrade» & Сгор production & $\begin{array}{l}\text { Construction of a seed plant in the Kharkiv region } \\
\text { (corn, oily cultures) }\end{array}$ \\
\hline \multirow{3}{*}{ «Astarta» } & Sugar production & $\begin{array}{l}\text { The increase in production by } 62 \% \text { - up to } \\
600 \text { thousand tons of sugar per year. } \\
\text { The increase in the share in the Ukrainian market } \\
\text { from } 19 \% \text { in } 2012 \text { to } 25-30 \%\end{array}$ \\
\hline & Сгор production & $\begin{array}{l}\text { The increase in the storage capacity of cereals } \\
\text { to } 800 \text { thousand tons. An increase in the harvest } \\
\text { of oil crops by } 127 \% \text { - to } 1,500,000 \text { tons per } \\
\text { year. Increase of sugar beet harvest by } 91 \%- \\
\text { up to } 4 \text { million tons }\end{array}$ \\
\hline & Dairy farming & $\begin{array}{l}\text { The growth of milk production by more than } \\
100 \% \text { - up to } 150 \text { thousand tons per year }\end{array}$ \\
\hline \multirow[t]{2}{*}{ «Nibulon» } & \multirow{2}{*}{$\begin{array}{l}\text { Crop production, } \\
\text { trading }\end{array}$} & $\begin{array}{l}\text { Implementation of a comprehensive program to } \\
\text { support and improve the technical condition of } \\
\text { elevators and reloading terminals }\end{array}$ \\
\hline & & $\begin{array}{l}\text { Increase of elevator capacity up to } 2.5 \text { thousand } \\
\text { tons of one-time storage }\end{array}$ \\
\hline «Гreative» & Сгор production & $\begin{array}{l}\text { The increase in the capacity for processing } \\
\text { soybean in } 3.1 \text { times - up to } 270 \text { thousand tons } \\
\text { per year }\end{array}$ \\
\hline «MHP» & Chicken production & Construction of Vinnytsia poultry complex \\
\hline
\end{tabular}

Note: developed by the authors on the basis of $[15,16]$

In the context of energy dependence on energy supply sources, alternative energy, more efficient use of resources, minimizing the consumption of energy resources, the use of energy-saving technologies and energy-saving technologies are of particular importance. Therefore, many agroholdings are trying to implement innovative projects for the installation of biogas equipment, or the construction of biogas plants. For example, the company «Myronivsky Hliboproduct» in December 2012 at the poultry farm «OrelLeader» in the Dnepropetrovsk region in the test mode, commissioned the first biogas plant with a capacity of 5 MW. The biogas plant operates on chicken litter and poultry farm waste. Ecoprod has already received funds from the EBRD for the construction and commissioning of a biogas plant with a capacity of $1.5 \mathrm{MW}$.

Kernel at the oil extraction plants uses the husk of sunflower as a fuel for the production of steam and electricity. In addition, Kernel began installation of one of its elevators experimental equipment for drying and cleaning the grain. The plant will operate on the husk of sunflower instead of the natural gas commonly used in industry.

To study the mechanism of agricultural holdings on the basis of determining the factors of influence in the context of its components, the method of multidimensional statistical analysis (factor analysis) was used. This analysis is designed to identify and quantify generalizing characteristics that sufficiently describe the entire set of initial and resulting indicators, thereby reflecting the

Table 3 patterns of production activities of agroholdings and the mechanism of their internal relationships.

Calculations were performed on the example of international agricultural holdings of Ukraine with the help of statistical package Statgraphics Centurion.

To develop a system of models of latent factors that affect the productive activities of agroholdings, it is advisable to compute integral indicators, namely:

1) the dynamics of investment in the expansion of production activities of agroholdings;

2) the dynamics of expenditures and sources of financing;

3) the dynamics of innovation activities (ID) of agroholdings.

Each component is characterized by a system of separate indicators.

Thus, the dynamics of investment in the expansion of production activities of agroholdings is described by such indicators:

$x_{1}$ - the share of agroholdings engaged in innovations;

$x_{2}-$ the total cost of agroholdings engaged in the introduction of new technologies;

$x_{3}$ - the amount of expenditure on research and development;

$x_{4}$ - the amount of expenditures for internal research work (R\&D);

$x_{5}$ - the sum of expenditures for external R\&Ds, decipher the abbreviation;

$x_{6}$-the amount of expenses for the acquisition of new technologies;

$x_{7}$ - the amount of expenses for the preparation of production for the introduction of new technologies;

$x_{8}$ - the amount of costs for the acquisition of machinery and equipment;

$x_{9}$ - the amount of costs of other costs associated with the introduction of new technologies.

The second component - the dynamics of costs and sources of financing of agricultural holdings, depends on the following indicators:

$x_{10}$ - the total cost;

$x_{11}$ - the amount of costs from own funds;

$x_{12}$ - the amount of expenses from the funds of Ukrainian investors;

$x_{13}$ - the amount of expenses at the expense of foreign investors;

$x_{14}$ - the amount of expenses from other sources.

Evaluation of the dynamics of the implementation of the ID of agroholdings is the third component, which is characterized by the following indicators:

$x_{15}$ - the share of agroholdings, which introduced innovations;

$x_{16}$ - the number of new technological processes introduced;

$x_{17}$ - the number of implemented new low-waste, resource-saving processes; 
$x_{18}$ - the number of titles for the development of innovative products;

$x_{19}$ - the number of titles for the development of innovative types of equipment;

$x_{20}$ - specific weight of realized innovative products by agroholdings in the industrial volume.

The first component - the dynamics of investment in the expansion of agricultural holdings are influenced by several factors, which we will consider by three factors. They account for $73.667 \%$ of the variability of the indicators that determine this component. Latent factors influencing the investment indicators of agroholdings are described by the following equations:

$$
\begin{aligned}
& F_{11}=0.705 x_{11}+0.217 x_{12}-0.023 x_{13}+0.094 x_{14}+0.152 x_{15}+ \\
& +0.771 x_{16}+0.377 x_{17}-0.747 x_{18}+0.857 x_{19}-0.931 x_{20}, \\
& F_{12}=0.549 x_{11}-0.634 x_{12}-0.195 x_{13}-0.201 x_{14}+0.766 x_{15}+ \\
& +0.366 x_{16}-0.213 x_{17}+0.282 x_{18}+0.927 x_{19}+0.075 x_{20}, \\
& F_{13}=0.077 x_{11}+0.029 x_{12}+0.918 x_{13}+0.909 x_{14}-0.026 x_{15}- \\
& -0.300 x_{16}-0.428 x_{17}-0.292 x_{18}-0.090 x_{19}+0.085 x_{20} .
\end{aligned}
$$

Thus, in the whole aggregate of agroholdings, the first factor, and, consequently, the most significant one is the generalizing factor (the first factor). It is formed by indicators formed in the direction of reducing factor loads (coefficients with variables): $x_{20}, x_{19}, x_{16}, x_{18}, x_{11}$ the remaining indicators can be neglected, since their factor loadings are less than 0.5 . The second factor is indicators $x_{19}, x_{15}, x_{12}, x_{11}$. The third factor of the state of agroholdings is characterized by the following sequence of indicators: $x_{13}, x_{14}$.

Thus, after analyzing, we have the first three latent factors that significantly affect the dynamics of innovative activity of enterprises, this is $x_{20}, x_{19}, x_{13}$.

The second component - the dynamics of costs and sources of financing of agricultural holdings is influenced by several factors, which we will also consider three latent factors, the equations of which look like:

$$
\begin{aligned}
& F_{21}=0.902 x_{1}+0.203 x_{2}+0.925 x_{15}+0.382 x_{16}- \\
& +0.112 x_{17}+0.536 x_{18}+0.787 x_{19}, \\
& F_{22}=-0.311 x_{1}+0.864 x_{2}+0.125 x_{15}+0.611 x_{16}- \\
& -0.018 x_{17}-0.778 x_{18}+0.308 x_{19}, \\
& F_{23}=-0.151 x_{1}-0.024 x_{2}+0.135 x_{15}+0.558 x_{16}+ \\
& +0.959 x_{17}-0.060 x_{18}-0.049 x_{19} .
\end{aligned}
$$

Rating indicators for these factors is: $x_{15}, x_{2}, x_{17}$. The second group of three factors explains by $85.489 \%$ the invariability of the indicators that determine this component.

On the third component of the activities of agroholdings - the dynamics of the introduction of the ID of agroholdings are also influenced by three factors. They explain by $81.837 \%$ the variability of the indicators that determine this component. The equation of this group of latent factors has the form:

$$
\begin{aligned}
& F_{31}=0.944 x_{1}+0.042 x_{2}+0.109 x_{3}+0.887 x_{15}+ \\
& +0.261 x_{16}-0.112 x_{17}+0.668 x_{18}+0.719 x_{19},
\end{aligned}
$$

$$
\begin{aligned}
& F_{32}=-0.179 x_{1}+0.796 x_{2}+0.781 x_{3}+0.309 x_{15}+ \\
& +0.689 x_{16}+0.042 x_{17}-0.690 x_{18}+0.484 x_{19}, \\
& F_{33}=-0.138 x_{1}-0.128 x_{2}+0.234 x_{3}+0,113 x_{15}+ \\
& +0.485 x_{16}+0.955 x_{17}+0.002 x_{18}-0.077 x_{19} .
\end{aligned}
$$

Thus, we have the seventh, eighth and ninth latent factors affecting the dynamics of the implementation of the IDs of agroholdings, which ratings of ratings have the following sequence: $x_{1}, x_{2}, x_{17}$. Thus, latent factors are modeled according to the three components of agricultural holdings.

\section{SWOT analysis of research results}

Strengths. There is a tendency of merging enterprises into agroholdings. This allows companies not only to control the quality and cost of products, but also increases the likelihood of obtaining credit resources.

Weaknesses. The agrarian business of Ukraine is experiencing a deficit of investment resources, but despite the risks, the Ukrainian agribusiness sector is an investmentattractive business.

Opportunities. Agroholdings become big «players» of the agro-sector, namely:

- «UkrLandFarming» - the leader in the production of grain and eggs in Ukraine;

- «Kernel» - the leader in the production and export of sunflower oil in Ukraine;

- «Myronivsky Hliboproduct» - the leader in the poultry meat production in Ukraine;

- «Astarta» - the leader of the sugar production in Ukraine.

Thanks to the effective development of the production activities of agroholdings, the sphere of the agrarian sector of the Ukrainian economy can become one of the main sources of increasing the country's economic growth. The development and implementation of new ones, improvement and improvement of existing approaches to managing instruments for financing agricultural holdings provide an additional impetus for the positive development and economic growth of the industry.

Threats. The infrastructure of the agro-industrial complex requires repair and reconstruction, to minimize the consumption of energy resources, some of the agricultural holdings started using biofuel.

\section{Conclusions}

1. The conducted research of tendencies of development of the enterprises of agrarian and industrial complex of Ukraine testifies, that recently the tendency to development and territorially-organizational consolidation of the enterprises of agrarian and industrial complex by formation of holdings, corporations, other agroformations is observed. At the same time, the role of investment processes, the development of methods for their implementation and effective management of them is growing.

2. To determine the patterns of functioning of agricultural holdings and the mechanisms of their internal interrelations, factors of influence on their activities in the context of its components have been investigated. Factor analysis is performed. On its basis, systems of models of 
latent factors that affect the components of agricultural holdings have been developed. These include:

- dynamics of investment in the expansion of produc-

tion activities of agroholdings;

- dynamics of expenditures and sources of financing;

- dynamics of innovative activity of agroholdings.

Modeled latent factors should be used for forecasting and as a basis for building development strategies for agroholdings.

\section{References}

1. Baronov V. V. Avtomatizatsiya upravleniya predpriyatiem. Moscow: INFRA-M, 2000. 239 p.

2. Agribusiness time series forecasting using Wavelet neural networks and metaheuristic optimization: An analysis of the soybean sack price and perishable products demand / Puchalsky W. et. al. // International Journal of Production Economics. 2018. Vol. 203. P. 174-189. doi: http://doi.org/10.1016/j.ijpe.2018.06.010

3. Shedy E. The Analysis and Estimation of Efficiency of Agroindustrial Formations of Holding Type of the Belgorod Region // Russian Journal of Agricultural and Socio-Economic Sciences. 2012. Vol. 2, Issue 2. P. 10-14. doi: http://doi.org/10.18551/ rjoas.2012-02.02

4. Bernstein H. Historical Materialism and Agrarian History // Journal of Agrarian Change. 2013. Vol. 13, Issue 2. P. 310-329. doi: http://doi.org/10.1111/joac.12020

5. The foundations theory and methodology of transfer of technologies for manufacturing high-tech production of the agrarian economy in Russia / Kuznetsov N. I. et. al. // The Agrarian Scientific Journal. 2018. Vol. 1. P. 65-68. doi: http:// doi.org/10.28983/asj.v0i1.251

6. Theory and practice of controlling at enterprises in international business / Malyarets L. et. al. // Economic Annals-XXI. 2017. Vol. 165, Issue 5-6. P. 90-96. doi: http://doi.org/10.21003/ ea.v165-19

7. Turner R., Ledwith A., Kelly J. Project management in small to medium-sized enterprises: Tailoring the practices to the size of company // Management Decision. 2012. Vol. 50, Issue 5. P. 942-957. doi: http://doi.org/10.1108/00251741211227627

8. Larson E., Larson R. Managing Small Projects. The Critical Steps. Watermark Learning, 2009. 12 p.
9. Pollack J., Adler D. Does Project Management Affect Business Productivity? Evidence from Australian Small to Medium Enterprises // Project Management Journal. 2014. Vol. 45, Issue 6. P. 17-24. doi: http://doi.org/10.1002/pmj.21459

10. Sidorov V., Babenko V., Bondarenko M. Researching factors of innovative activities of agrarian business of ukraine under globalization of the world economy // Innovative Technologies and Scientific Solutions for Industries. 2017. Issue 2 (2). P. 70-76. doi: http://doi.org/10.30837/2522-9818.2017.2.070

11. Pyrez-Ezcurdia A., Marcelino-Sdeba S. The small project paradox in SMEs. Prime // Journal of Business Administration and Management. 2012. Issue 2 (9). P. 687-692.

12. Zott C., Amit R., Massa L. The Business Model: Recent Developments and Future Research // Journal of Management. 2011. Vol. 37, Issue 4. P. 1019-1042. doi: http://doi.org/ $10.1177 / 0149206311406265$

13. Vytlynskyi V. V., Babenko V. A. Obzor metodov kolychestvennoi otsenky vlyianyia ryskov $\mathrm{v}$ ahropromishlennom proyzvodstve // Rynkova transformatsiia ekonomiky. 2012. Vol. 14. P. 78-87.

14. Babenko V. A. Metody i modeli otsenivaniya riska na primere proizvodstva produktsii sel'skogo khozyaystva // Visnik Khmel'nits'kogo natsional'nogo universitetu. 2018. Issue 1. P. 182-186.

15. Agrovypusk agrokholdinga «Kharmeliya» // Agrokholding «Kharmeliya». URL: http://www.agrogeneration.com/ua/ (Last accessed: 17.06.2018)

16. Top 100 latyfundystov Ukrayni // Natsyonalnii ahroportal «Latifundist». 2014. URL: http://latifundist.com/rating/top100/ 27866-harmelia (Last accessed: 21.05.2018)

Babenko Vitalina, Doctor of Economic Sciences, Professor, Department of International Business and Economic Theory, V. N. Karazin Kharkiv National University, Ukraine, e-mail: vitalinababenko@karazin.ua, ORCID: http://orcid.org/0000-0002-4816-4579

Sidorov Vadim, PhD, Professor, V. N. Karazin Kharkiv National University, Ukraine, e-mail: vi.sidorov@karazin.ua, ORCID: https:// orcid.org/0000-0002-5655-2221

Savin Ruslan, Postgraduate Student, Department of International Economic Relations, V. N. Karazin Kharkiv National University, Ukraine, e-mail: irtb@karazin.ua, ORCID: https://orcid.org/00000003-4634-0660 